\title{
Perancangan Sistem Informasi Perpustakaan Berbasis Web pada SMP Negeri 1 Ngaringan
}

\author{
Muhammad Taufiq Zakki Hidayat*, Herry S. Mangiri, Handini Arga Damar Rani \\ SMP Negeri 1 Ngaringan, Universitas Ivet, Universitas Ivet \\ *dr.azamjr@gmail.com
}

\begin{abstract}
ABSTRAK
Tujuan penelitian ini adalah 1). Menghasilkan sebuah aplikasi Sistem Informasi Perpustakaan sesuai kebutuhan yang meliputi data inventaris buku, data jurnal peminjaman dan pengembalian, data pencarian koleksi buku, dan data keanggotaan perpustakaan pada sekolah SMP Negeri 1 Ngaringan; 2). Pengembangan sistem informasi perpustakaan berbasis web sebagai rujukan pengambilan keputusan dan kebijakan satuan pendidikan dalam penilaian kinerja kepala sekolah. Serta sebagai layanan informasi bagi civitas akademik SMP Negeri 1 Ngaringan; 3). Sebagai salah satu syarat untuk memperoleh gelar Sarjana pada program studi Strata 1 Pendidikan Informatika pada Fakultas Saintek di Universitas Ivet.

Penelitian ini merupakan penelitian Reseacrh and Development berupa aplikasi sistem informasi perpustakaan berbasis web yang dijalankan secara lokal. Model pengembangan yang digunakan adalah waterfall yang meliputi, analisis kebutuhan, desain, implementasi dan pengujian akhir. Pada tahapan desain penelitian ini menggunakan model Unified Modelling Language (UML) sebagai acuan dalam sistem yang dibangun. Sedangkan pada tahap pengujiannya pada sistem informasi ini berfokus pada aspek functionality dan usability.

Hasil penelitian diperoleh sebagai berikut; (1) sistem informasi perpustakaan berbasis web dikembangkan dengan codeigniter dan model pengembangan waterfall dari tahapan analisis, desain, implementasi dan pengujian. (2) pada aspek functionality fungsi pada setiap sistem berjalan dengan dengan keberhasilan $100 \%$. Sedangkan Pada hasil pengujian yang dilakukan sistem ini masuk dalam kategori "Sangat Kuat/Sangat Layak" dengan nilai 96,18\% pada aspek usability.

Kata kunci : Sistem Informasi, Perpustakaan, Website.
\end{abstract}

\begin{abstract}
The purpose of this study is 1). Generate a Library Information System application according to needs that include book inventory data, journal data on borrowing and repayment, search data for book collections, and library membership data at SMP Negeri 1 Ngaringan; 2). Development of desktop webbased library information systems as a reference for decision making and education unit policies in evaluating the performance of school principals. As well as information services for the academic community of SMP Negeri 1 Ngaringan; 3). As one of the requirements for obtaining a Bachelor's degree, in the Undergraduate Study Program of Informatics Education at the Faculty of Science at Ivet University.

This research is a Research and Development research in the form of a web-based library information system application that is run locally. The development model used is a waterfall which includes, needs analysis, design, implementation and final testing. At the design stage of this study using the Unified Modeling Language (UML) model as a reference in the system being built. Whereas the testing phase of this information system focuses on aspects of functionality and usability.

The results of the study were obtained as follows;(1) web-based library information system is developed with codeigniter and waterfall development models from the stages of analysis, design, implementation and testing. (2) the functionality aspect of each system runs with $100 \%$ success. While the results of testing conducted by this system are included in the category of "Very Strong / Very Worthy" with a value of $96.18 \%$ in the usability aspect.
\end{abstract}

Keywords: Information System, Library, Website. 


\section{PENDAHULUAN}

Kebutuhan teknologi informasi di era globalisasi saat ini berperan penting sebagai pendorong gerak dalam dunia pendidikan. Kebutuhan akan hak akses informasi yang begitu banyak, memberikan dampak akan kebutuhan manusia secara cepat dan instan terutama dalam dunia pendidikan.

Pendidikan yang terfasilitasi dengan teknologi yang baik akan memberi dampak yang luas bagi peserta didik dalam memenuhi kebutuhan akan ilmu pengetahuan sehari-hari. Dan sebagai penggunaan media informasi teknologi salah satunya dalam pendidikan adalah pemanfaatan media informasi perpustakaan bagi civitas akademika. Perpustakaan sekolah harus memenuhi standar nasional dengan mengacu pada standar nasional pendidikan, serta wajib memiliki koleksi buku teks pelajaran yang ditetapkan sebagai buku wajib pada lembaga pendidikan yang bersangkutan dalam jumlah yang mencukupi untuk melayani seluruh peserta didik.

Disamping itu, keberadaan kepala perpustakaan juga harus memenuhi syarat yang sudah ditentukan oleh Peraturan Menteri Pendidikan Nasional yang tertuang dalam Permendiknas nomor 26 tahun 2008 dalam mengelola perpustakaan, yaitu kepala perpustakaan harus memiliki sertifikat standar tenaga perpustakaan yang dikeluarkan oleh lembaga resmi yang bekerja sama dengan Dinas Pendidikan setempat dengan beban kerja 12 jam.

Berdasarkan hasil observasi dilapangan bahwasanya perpustakaan di SMP Negeri 1 Ngaringan saat ini masih dikelola oleh pustakawan, hal ini dikarenakan keberadaan kepala perpustakaan belum ada. Terlebih lagi di SMP Negeri 1 Ngaringan juga belum ada guru maupun pegawai yang memiliki sertifikat standar untuk pengelolaa perpustakaan sebagaimana ketentuan pemerintah tentang tenaga perpustakaan. Pengelolaan perpustakaan saat ini masih menerapkan pendataan administrasi secara tertulis maupun konvensional. Hal ini didasarkan pada hasil observasi dan analisa langsung dilapangan.

Sistem pengelolaan perpustakaan di SMP Negeri 1 Ngaringan saat ini masih menggunakan pencatatan secara tertulis, mulai dari pencatatan inventaris buku, jurnal peminjaman dan pengembalian, denda keterlambatan atau pelanggaran, hingga laporan pengelolaan administrasi hingga proses pencarian katalog buku yang masih belum terkomputerisasi.

Pengelolaan saat ini juga memiliki resiko bila menggunakan pencatatan yang dibukukan, mulai dari hilangnya arsip, tercecer, bahkan rusak akibat terkena banjir yang pernah terjadi di SMP Negeri 1 Ngaringan karena letak geografis daerah dan kondisi alam yang sudah berbeda. Sehingga hal ini dapat berdampak pada kurang maksimal dalam memberikan layanan informasi bagi pengguna perpustakaan.

Bagi pustakawan hal yang sering dirasakan apabila masih menerapkan pengelolaan yang dibukukan, diantaranya sulitnya menemukan arsip lama apabila digunakan sebagai rujukan akreditasi sekolah, sulitnya pembuatan laporan penggunaan perpustakaan tiap akhir tahun dan terkendalanya proses yang memakan waktu dalam kegiatan pelayanan perpustakaan.

Bagi siswa maupun pengunjung perpustakaan sering kali ditemukan sulitnya mengakses informasi yang ada diperpustakaan selama ini, mulai dari koleksi buku, peminjaman dan pengembalian buku, referensi jurnal buku, 
maupun informasi yang bersumber dari perpustakaan.

Berdasarkan pemaparan di atas, maka pada penelitian ini penerapan konsep sistem informasi perpustakaan berbasis web, sebagai salah satu alternatif dalam memaksimalkan pelayanan, serta sebagai sarana penunjang pendidikan di SMP Negeri 1 Ngaringan.

Disamping itu sebagai bahan penguatan dan dasar penelitian ini, peneliti juga mengacu pada jurnal penelitian yang sudah pernah dibuat sebagai sumber pada pengembangan dan perancangan sistem informasi perpustakaan di SMP Negeri 1 Ngaringan. Dimana salah satunya pada jurnal Agus Ervianto dalam penelitiannya Rancang Bangun Sistem Informasi Perpustakaan Berbasis Web dengan PHP dan Mysql di Perpustakaan SMA YPPI 1 Surabaya dengan pengembangan model sistem development life cycle serta perancangan sistem menggunakan model DFD dan ERD Level.

Dalam jurnal penelitian tersebut, pada penelitian menunjukkan bahwa hasil tampilan layout program aplikasi dirasa masih sederhana. Pengembangan hanya berfokus pada terpenuhinya kebutuhan akan pengelolaan buku, peminjaman, guru dan admin, sehingga belum terpenuhi pada kebutuhan pengguna lainnya yaitu, siswa, operator perpustakaan dan laporan administrasi perpustakaan.

Sehingga peneliti berpendapat perlu adanya pengembangan lebih lanjut pada sistem informasi yang ada pada jurnal untuk diterapkan di perancangan sistem informasi perpustakaan di SMP Negeri 1 Ngaringan sesuai dengan kebutuhan-kebutuhan dilapangan sebagai mana hasil dari pemaparan latar belakang pada penelitian ini.

Pada penelitian yang peneliti kembangkan, perancangan sistem informasi perpustakaan di SMP Negeri 1 Ngaringan menggunakan metode pengembangan Research and Development dengan model pengembangan sistem waterfall melalui tahapan analisis, desain sistem, kode program, hingga pengujian sistem. Hal ini merujuk pada kebutuhan yang ada dilapangan selama peneliti melakukan obervasi, wawancara dan dokumentasi.

Kebutuhan yang akan dibangun pada sistem informasi ini meliputi kebutuhan akan invetarisasi buku, jurnal peminjaman dan pengembalian, pengelolaan data kelas, data siswa, data operator, data admin serta hasil cetak laporan administrasi perpustakaan secara berkala. Serta memaksimalkan tampilan layout sistem agar lebih user friendly. Selain itu sistem akan diterapkan secara offline agar mempermudah dalam instalasi dan perawatan sistem. Sistem informasi yang dikembangkan juga dilakukan pengujian untuk menghasilkan kualitas sistem yang layak digunakan dimana sistem yang diujikan mengacu pada aspek functionality dan aspek usability.

Sehingga diharapkan dengan sistem informasi perpustakaan ini dapat membantu petugas perpustakaan SMP Negeri 1 Ngaringan dalam mengelola administrasi perpustakaan dan layanan perpustakaan dengan baik.

\section{METODEPENELITIAN}

A. Pendekatan dan Jenis Penelitian

Berdasarkan latar belakang dan tujuan, maka metode penelitian yang digunakan dalam pengembangan sistem informasi ini adalah dengan metode Research and Development. Dalam pengertiannya menurut Sujadi (2003:164) dalam bukunya Metodologi Penelitian Pendidikan bahwasanya penelitian pengembangan Research and Development (R\&D) diartikan sebagai suatu proses atau langkah-langkah untuk mengembangkan suatu produk baru atau menyempurnakan 
produk yang telah ada yang dapat dipertanggungjawabkan.

Menurut Sugiyono (2012:297) dalam bukunya yang berjudul Metode Penelitian Kuantitatif Kualitatif dan R\&D bahwa metode penelitian dan pengembangan adalah metode penelitian yang digunakan untuk menghasilkan produk tertentu dan menguji keefektifan produk tersebut. Sedangkan menurut Nana Syaodih Sukmadinata (2005:164), bahwa penelitian dan pengembangan Research and Development adalah suatu proses atau langkah-langkah untuk mengembangkan suatu produk baru atau menyempurnakan produk yang telah ada, yang dapat dipertanggungjawabkan.

Berdasarkan pokok pembahasan diatas bahwa penelitian ini juga menggunakan model waterfall dalam mengembangkan sistem informasi perpustakaan. Bahwa model waterfall merupakan model sekuensial dimana aktivitas selanjutnya dimulai ketika kegiatan sebelumnya sudah selesai. Sehingga inti dari metode waterfall ini mengerjakan suatu sistem dilakukan secara berurutan atau secara linier.

\section{B. Sampel Penelitian}

Sampel merupakan bagian dari jumlah dan karakteristik yang dimiliki oleh populasi (Sugiyono, 2012:81). Sampel pada penelitian ini adalah siswa, guru, operator perpustakaan (pustakawan) dan seorang ahli dalam bidang software. Sampel penelitian ini di fokuskan pada aspek kebutuhan yaitu, fucntionality, usability. Pada aspek fucntionality subjek penelitian adalah guru, pustakawan dan ahli media yang masing masing diambil 1 orang. Pengumpulan data pada aspek functionality oleh peneliti menggunakan alat ukur berupa lembar kuesioner skala Guttman, data nantinya yang akan diperoleh berupa data interval atau rasio alternatif yaitu "Ya" dan "Tidak". Dimana masing-masing bernilai $\mathrm{Ya}=1$ yang bermakna positif, dan Tidak $=0$ bermakna negatif.

Sedangkan pada aspek usability sampel penelitian adalah beberapa siswa, guru dan pustakawan di SMP Negeri 1 Ngaringan, dengan jumlah responden 30 orang (Nielsen, 1993:224). Dengan menggunakan teknik kuesioner J.R Lewis dengan jumlah butir pertanyaan 19 soal dengan skala pilihan masing-masing 5 pilihan.

\section{Prosedur Penelitian}

1. Analisis Kebutuhan

Tahap analisis kebutuhan dilakukan dengan observasi secara langsung dan wawancara kepada objek penelitian. Observasi dilakukan langsung diperpustakaan SMP Negeri 1 Ngaringan. Dalam prosesnya peneliti juga terlibat langsung dalam kegiatan di perpustakaan. Dari hasil observasi ini peneliti mengetahui dan memahamai masalah yang ada dan kebutuhan apa saja yang diperlukan dalam membangun sistem informasi perpustakaan.

\section{Desain Sistem}

Desain sistem merupakan gambaran dari analisis kebutuhan dari sistem yang akan dibangun pada penelitian ini. Desain ini meliputi, Unified Modelling Language (UML), database, dan tampilan antarmuka (user interface). UML adalah desain sistem menggunakan use case, sequence diagram dan activity diagram.

\section{Implementasi}

Implementasi dibangun berdasarkan desain rancangan awal dari sistem informasi perpustakaan ini. Implementasi sistem dibuat ke dalam bahasa pemograman PHP dan ke database MySQL. Implementasi kode menghubungkan beberapa fitur yang dibutuhkan dengan tambahan codeigniter. 
Tahap ini diharapkan agar semua fungsi program berjalan sesuai desain yang dibuat.

4. Pengujian Sistem

Pengujian sistem informasi yang dibangun ini menggunakan salah satu standar yang dipakai untuk menguji perangkat lunak, yaitu menggunakan standar ISO 9126. Standar ini untuk mengetahui kualitas perangkat lunak yang dibangun dengan kriteria pengujian yang meliputi aspek fungsional, aspek kebergunaan (usability), aspek efisiensi, aspek keterpeliharaan (maintainability), aspek portabilitas dan aspek kehandalan (reliability).

Proses penelitian ini dilaksanakan selama bulan Mei sampai dengan bulan Juli 2019. Yang bertempat di SMP Negeri 1 Ngaringan yang beralamat di Jl. Raya Blora 67A. Ngaringan, Grobogan, Jawa Tengah.

D. Teknik Pengumpulan Data

Adapun teknik pengumpulan data selama masa penelitian yang digunakan diantaranya; 1) Observasi, 2) Wawancara, 3) Dokumentasi, 4) Angket.

\section{E. Teknik Analisis Data}

Teknik analisis data yang digunakan pada penelitian ini menggunakan instrumen angket (questioner). Tingkat koresponden diambil sejumlah 3 orang pada uji analisis aspek functionality. Sedangkan sejumlah 30 orang sebagai pengguna sistem informasi perpustakaan berbasis web dekstop ini,
Volume 3, Nomor 1, Juni 2020

diantaranya siswa, guru dan pustakawan pada aspek usability.

Data penelitian ini akan menghasilkan prosentase dari setiap rata-rata nilai yang diubah dalam skala kualitatif dalam bentuk interval. Dari setiap nilaidiambil hasil rata-rata. Hasil nilai rata-rata dijumlahkan semua, dengan sebanyak korespondensi yang ditetapkan, sehingga dapat ditemukan nilai tertinggi dan nilai terendah.

\section{HASIL DAN PEMBAHASAN}

A. Deskripsi Seting Penelitian

Perancangan sistem informasi perpustakaan di SMPN 1 Ngaringan didasarkan atas hasil identifikasi di lapangan yang menunjukkan bahwa, proses pelaksanaan peminjaman dan pengembalian pembukuan secara manual. Sehingga menyebabkan proses pengambilan keputusan serta kebijakan akan memakan waktu yang cukup lama).

Nilai Interval Nilai yang sudah didapatkan selanjutnya dimasukkan ke dalam perhitungan interval guna mendapatkan prosentase tiap kategori pada angket yang digunakan.

Nilai rentang data yang diperoleh merupakan hasil dari nilai tertinggi yang dikurangi nilai terendah.

$$
\begin{aligned}
& \text { Rentang data }=100 \%-20 \% \\
& =80 \%
\end{aligned}
$$

Pada sistem informasi yang dibangun ini, kebutuhan pengembangan sistem ditentukan pada analisis seluruh kebutuhan sistem secara lengkap untuk mempermudah sistem bekerja dengan baik. Adapun analisis dari kebutuhan sistem ini yaitu:

1. Analisis Kebutuhan Fungsional

Kebutuhan fungsional adalah jenis kebutuhan yang berisikan proses-proses apa saja yang nanti dilakukan oleh sistem. Kebutuhan fungsional pada sistem informasi 
perpustakaan di SMP Negeri 1 Ngaringan meliputi:

a. Sistem harus dapat melakukan entry data yang meliputi, data buku, kelas, siswa, administrasi perpustakaan.

b. Sistem harus dapat melakukan input data login user sebagai operator maupun admin dalam mengelola administrasi perpustakaan.

c. Sistem harus dapat menampilkan informasi yang dapat diakses secara umum maupun secara khusus (login).

2. Analisis Kebutuhan Non Fungsional

Kebutuhan nonfungsional adalah jenis kebutuhan yang dimiliki oleh sistem, yang meliputi: 1) Perangkat Lunak (Software), 2) Perangkat Keras (Hardware).

\section{B. Deskripsi Data Penelitian}

1) Tahap Desain

Desain sistem yang digunakan dalam pengembangan sistem perpustakaan ini meliputi perancangan Unified Modelling Language (UML), basis data (database), dan desain antarmuka (user interface). yaitu:

a. Desain Unified Modelling Language (UML)

1. Use Case Diagram

Use Case diagram menunjukkan fungsionalitas suatu sistem atau kelas dan bagaimana sistem ini berinteraksi dengan luar (aktor). Use Case diagram dapat digunakan untuk memperoleh kebutuhan sistem dan memahami bagaimana sistem bekerja. Pada pengembangan sistem perpustakaan ini menjelaskan hubungan antara aktor, input maupun output dalam sistem.

2. Class Diagram

Class diagram sistem informasi perpustakaan ini dapat dilihat dari gambar berikut ini:

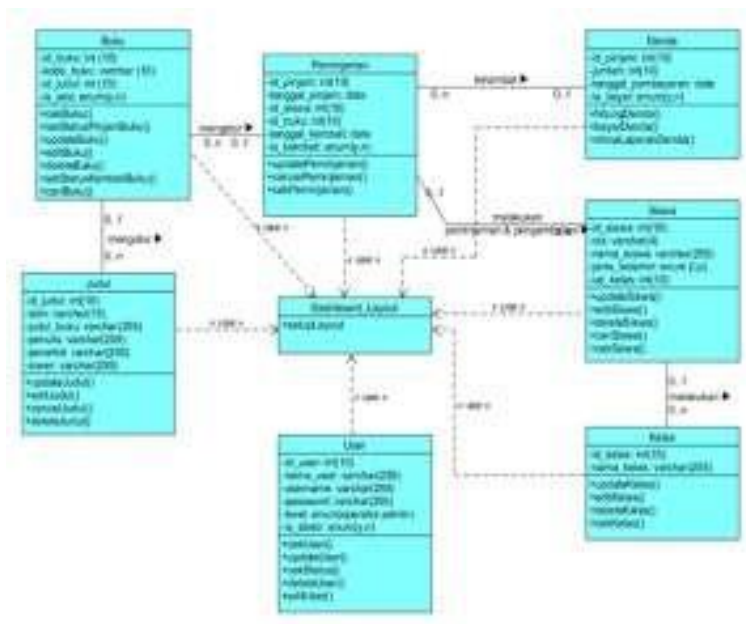

Gambar 1. Class Diagram

3. Activity Diagram

Activity Diagram atau diagram aktifitas adalah gambaran dari aliran kerja dari sebuah sistem yang dibuat.

4. Sequence Diagram

Sequence diagram menggambar interaksi antar objek di dalan dan sekitar sistem.

b. Desain Basis Data (Database)

Perancangan basis data dalam sistem informasi perpustakaan di SMP Negeri 1 Ngaringan diuraikan dalam proses pemodelan yang menunjukkan hubungan antar data yang saling berelasi yang dipresentasikan dalam bentuk model ERD (Entity Relationship Diagram).

c. Desain Antarmuka (User Interface)

Desain antar muka dari sistem informasi perpustakaan di SMP Negeri 1 Ngaringan sebagai berikut:

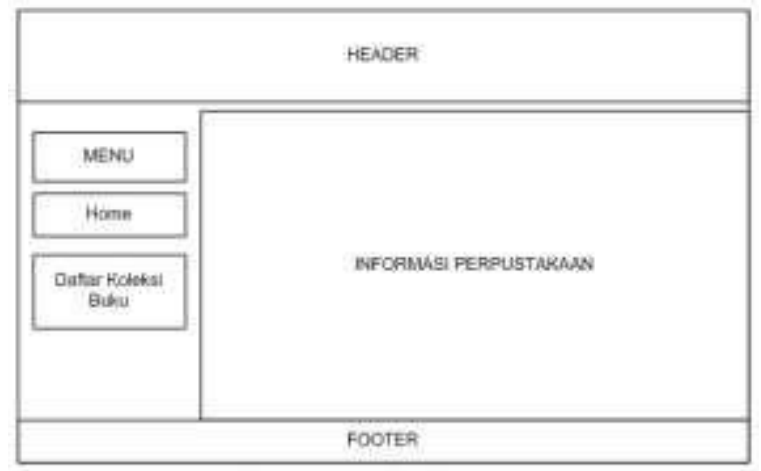

Gambar 2. Desain interface 
2) Tahap Implementasi.

Gambar 5. Implementasi Halaman Buku

a. Implementasi Basis Data

Proses pembuatan dan pengelolaan database pada sistem informasi ini dijalankan pada phpmyadmin. Adapun tahapan pembuatan dengan melakukan "create new database", dengan memberi nama database "dbperpus".

\section{Databases}

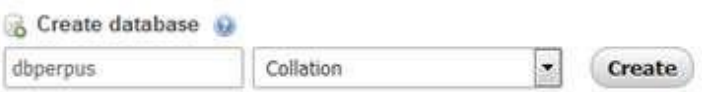

Gambar 3. Membuat Database Baru

b. Implementasi Antarmuka

Perancangan implementasi antarmuka pada sistem perpustakaan ini terbagi menjadi dua halaman, yaitu halaman umum yang memuat informasi daftar buku yang tersedia di perpustakaan dan halaman admin yang berisikan tata kelola sumber daya informasi yang dibutuhkan untuk mengelola sistem informasi perpustakaan ini. Adapun rincian desain antarmuka dari sistem ini diantaranya:

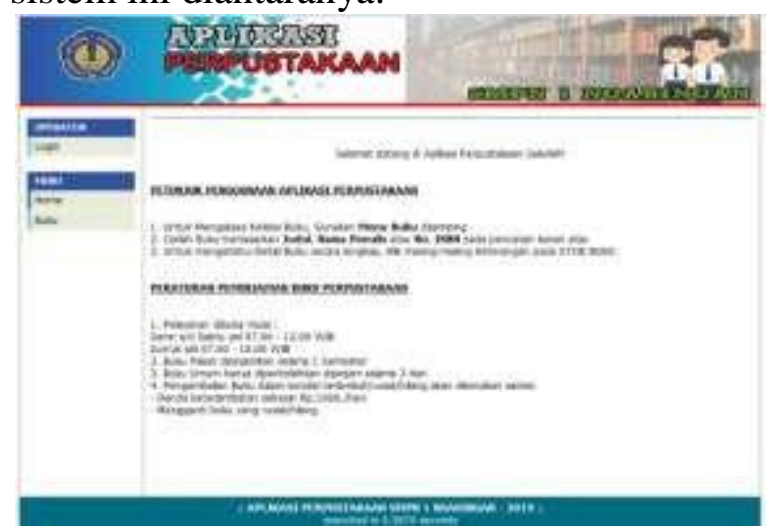

Gambar 4. Implementasi Halaman Utama 
Gambar 6. Implementasi Halaman Login

Gambar 7. Implementasi Halaman

Transaksi Peminjaman

Gambar 8. Implementasi Halaman Proses Pengembalian Buku

Gambar 9 Implementasi Tampilan Halaman Cetak Laporan

C. Pengukuran Akhir dan Hasil Pengujian

Pengukuran dan pengujian hipotesis ini menggunakan metode black box testing dimana serangkaian tes uji coba yang dikerjakan pada interface perangkat lunak. Pengujian ini didemonstrasikan dengan
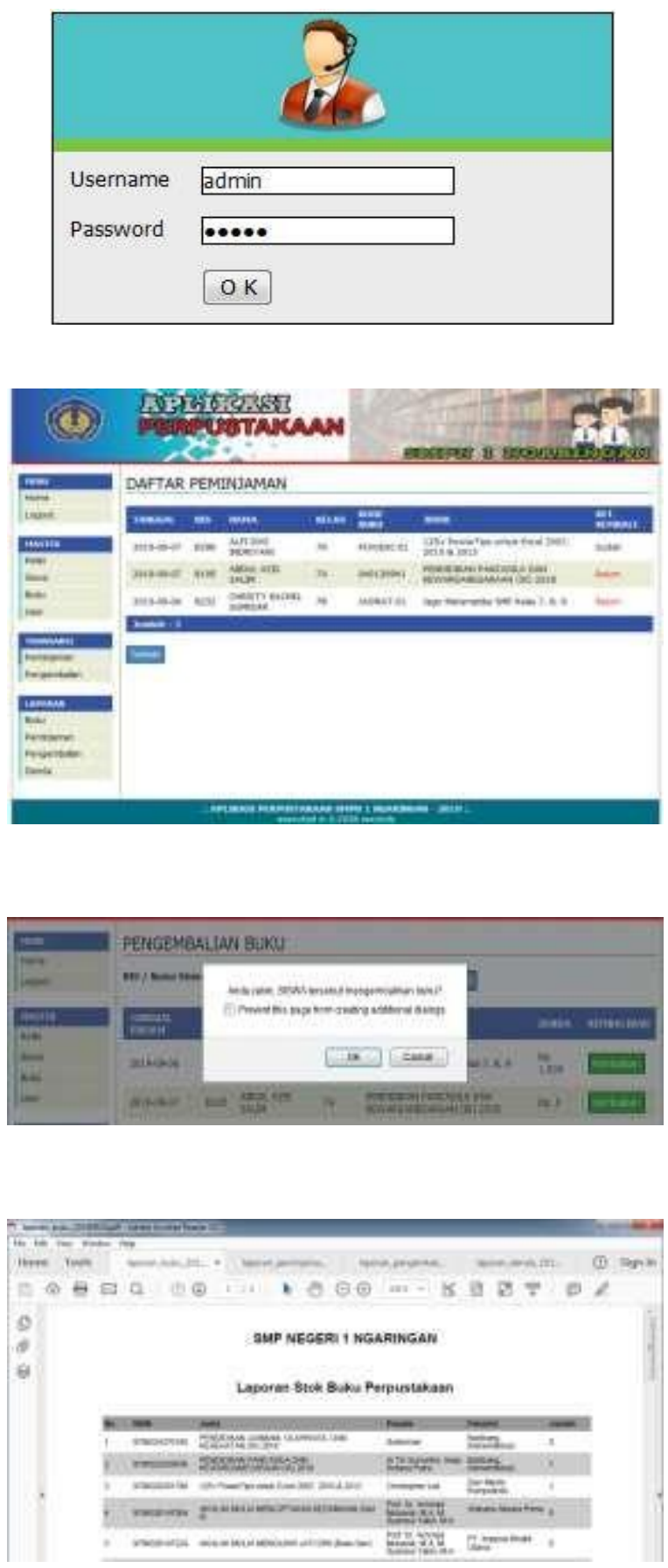
pengujian fungsi perangkat lunak aplikasi, apakah aplikasi berjalan dengan benar atau tidak. Dan dari pengujian ini dibuatlah kuesioner untuk menghasilkan nilai dari sistem yang dibangun.

\section{1) Pengujian Functionality}

Pengujian functionality dilakukan oleh guru, pustakawan SMP Negeri 1 Ngaringan dan ahli software dengan menggunakan checklist uji functionality sehingga diperoleh hasil sebagai berikut:

Tabel 1. Hasil Pengujian Functionality

\begin{tabular}{|c|c|c|c|}
\hline NO & FUNGSI & PERNYATAAN & TIDAK \\
\hline \multicolumn{4}{|c|}{ UMUM } \\
\hline 1 & Localhost & $\begin{array}{l}\text { Fungsi } \\
\text { menampilkan } \\
\text { aplikasi } \\
\text { perpustakaan } \\
\text { sudah berfungsi } \\
\text { dengan baik }\end{array}$ & 3 \\
\hline 2 & Home & $\begin{array}{lr}\text { Fungsi tampilan } \\
\text { halaman depan } \\
\text { sudah berfungsi } \\
\text { dengan benar }\end{array}$ & 3 \\
\hline 3 & $\begin{array}{l}\text { Pencarian } \\
\text { Koleksi Buku } \\
\text { berdasarkan } \\
\text { ISBN Buku }\end{array}$ & $\begin{array}{lr}\text { Fungsi } & \text { pencarian } \\
\text { koleksi } & \text { buku } \\
\text { berdasarkan } & \text { ISBN } \\
\text { buku } & \text { sudah } \\
\text { berfungsi } & \text { dengan } \\
\text { benar } & \\
\end{array}$ & 3 \\
\hline 4 & $\begin{array}{l}\text { Pencarian } \\
\text { Koleksi Buku } \\
\text { berdasarkan } \\
\text { penulis }\end{array}$ & $\begin{array}{lr}\text { Fungsi } & \text { pencarian } \\
\text { koleksi } & \text { buku } \\
\text { berdasarkan } & \\
\text { penulis } & \text { sudah } \\
\text { berfungsi } & \text { dengan } \\
\text { benar } & \\
\end{array}$ & 3 \\
\hline 5 & $\begin{array}{l}\text { Pencarian } \\
\text { Koleksi Buku } \\
\text { berdasarkan } \\
\text { judul }\end{array}$ & $\begin{array}{lr}\text { Fungsi pencarian } \\
\text { koleksi } \quad \text { buku } \\
\text { berdasarkan judul } \\
\text { sudah berfungsi } \\
\text { dengan benar }\end{array}$ & 3 \\
\hline \multicolumn{4}{|c|}{ USER/OPERATOR (PUSTAKAWAN) } \\
\hline 6 & Login & $\begin{array}{l}\text { Fungsi login } \\
\text { sudah berfungsi } \\
\text { dengan benar }\end{array}$ & 3 \\
\hline 7 & Logout & $\begin{array}{l}\text { Fungsi } \begin{array}{l}\text { Logout } \\
\text { sudah berfungsi } \\
\text { dengan benar }\end{array} \\
\end{array}$ & 3 \\
\hline 8 & $\begin{array}{l}\text { Tampilan } \\
\text { Home }\end{array}$ & $\begin{array}{l}\text { Fungsi home } \\
\text { sudah berfungsi } \\
\text { dengan benar }\end{array}$ & 3 \\
\hline 9 & \begin{tabular}{l}
\multicolumn{2}{l}{ Pengelolaan } \\
Menu Data \\
Kelas
\end{tabular} & $\begin{array}{l}\text { Fungsi data kelas } \\
\text { sudah berfungsi } \\
\text { dengan benar }\end{array}$ & 3 \\
\hline
\end{tabular}

\begin{tabular}{|c|c|c|c|}
\hline & Pengelolaan & Fungsi data siswa & \\
\hline 10 & $\begin{array}{l}\text { Menu Data } \\
\text { Siswa }\end{array}$ & $\begin{array}{l}\text { sudah berfungsi } \\
\text { dengan benar }\end{array}$ & 3 \\
\hline 11 & $\begin{array}{l}\text { Pengelolaan } \\
\text { Menu Data } \\
\text { Buku }\end{array}$ & $\begin{array}{l}\text { Fungsi data buku } \\
\text { sudah berfungsi } \\
\text { dengan benar }\end{array}$ & 3 \\
\hline 12 & $\begin{array}{l}\text { Pengelolaan } \\
\text { Menu Data } \\
\text { Peminjaman }\end{array}$ & $\begin{array}{l}\text { Fungsi data } \\
\text { peminjaman } \\
\text { sudah berfungsi } \\
\text { dengan benar }\end{array}$ & 3 \\
\hline 13 & $\begin{array}{l}\text { Pengelolaan } \\
\text { Menu Data } \\
\text { Pengembalian }\end{array}$ & $\begin{array}{l}\text { Fungsi data } \\
\text { Pengembalian } \\
\text { sudah berfungsi } \\
\text { dengan benar }\end{array}$ & 3 \\
\hline 14 & $\begin{array}{l}\text { Menu Cetak } \\
\text { Koleksi Buku }\end{array}$ & $\begin{array}{lr}\text { Fungsi } & \text { cetak } \\
\text { koleksi } & \text { buku } \\
\text { sudah berfungsi } & \text { dengan benar }\end{array}$ & 3 \\
\hline 15 & $\begin{array}{l}\text { Menu Cetak } \\
\text { Laporan } \\
\text { Peminjaman }\end{array}$ & $\begin{array}{l}\text { Fungsi cetak } \\
\text { laporan } \\
\text { peminjaman } \\
\text { sudah berfungsi } \\
\text { dengan benar }\end{array}$ & 3 \\
\hline 16 & $\begin{array}{l}\text { Menu Cetak } \\
\text { Laporan } \\
\text { Pengebalian }\end{array}$ & $\begin{array}{l}\text { Fungsi cetak } \\
\text { laporan } \\
\text { pengembalian } \\
\text { sudah berfungsi } \\
\text { dengan benar }\end{array}$ & 3 \\
\hline 17 & $\begin{array}{l}\text { Menu Cetak } \\
\text { Laporan } \\
\text { Denda }\end{array}$ & $\begin{array}{lr}\text { Fungsi } & \text { cetak } \\
\text { laporan } & \text { denda } \\
\text { sudah berfungsi } & \text { dengan benar }\end{array}$ & 3 \\
\hline \multicolumn{4}{|c|}{ ADMINISTRATOR } \\
\hline 18 & Login & $\begin{array}{lr}\text { Fungsi } & \text { login } \\
\text { sudah berfungsi } \\
\text { dengan benar }\end{array}$ & 3 \\
\hline 19 & Logout & $\begin{array}{l}\text { Fungsi } \text { Logout } \\
\text { sudah berfungsi } \\
\text { dengan benar }\end{array}$ & 3 \\
\hline 20 & $\begin{array}{l}\text { Tampilan } \\
\text { Home }\end{array}$ & $\begin{array}{l}\text { Fungsi home } \\
\text { sudah berfungsi } \\
\text { dengan benar }\end{array}$ & 3 \\
\hline 21 & $\begin{array}{l}\text { Pengelolaan } \\
\text { Menu User } \\
\text { (operator) }\end{array}$ & $\begin{array}{l}\text { Fungsi } \text { user sudah } \\
\text { berfungsi dengan } \\
\text { benar }\end{array}$ & 3 \\
\hline 22 & $\begin{array}{l}\text { Pengelolaan } \\
\text { Menu Data } \\
\text { Kelas }\end{array}$ & $\begin{array}{l}\text { Fungsi data kelas } \\
\text { sudah berfungsi } \\
\text { dengan benar }\end{array}$ & 3 \\
\hline 23 & $\begin{array}{l}\text { Pengelolaan } \\
\text { Menu Data } \\
\text { Siswa }\end{array}$ & $\begin{array}{l}\text { Fungsi data siswa } \\
\text { sudah berfungsi } \\
\text { dengan benar }\end{array}$ & 3 \\
\hline 24 & \begin{tabular}{l}
\multicolumn{2}{l}{ Pengelolaan } \\
Menu Data \\
Buku
\end{tabular} & $\begin{array}{l}\text { Fungsi data buku } \\
\text { sudah berfungsi } \\
\text { dengan benar }\end{array}$ & 3 \\
\hline 25 & $\begin{array}{l}\text { Pengelolaan } \\
\text { Menu Data } \\
\text { Peminjaman }\end{array}$ & $\begin{array}{l}\text { Fungsi data } \\
\text { peminjaman } \\
\text { sudah berfungsi } \\
\text { dengan benar }\end{array}$ & 3 \\
\hline 26 & $\begin{array}{l}\text { Pengelolaan } \\
\text { Menu Data } \\
\text { Pengembalian }\end{array}$ & $\begin{array}{l}\text { Fungsi data } \\
\text { Pengembalian } \\
\text { sudah berfungsi }\end{array}$ & 3 \\
\hline
\end{tabular}




\begin{tabular}{|c|c|c|c|}
\hline \multicolumn{4}{|c|}{ dengan benar } \\
\hline 27 & $\begin{array}{l}\text { Menu Cetak } \\
\text { Koleksi Buku }\end{array}$ & $\begin{array}{lr}\text { Fungsi } & \text { cetak } \\
\text { koleksi } & \text { buku } \\
\text { sudah berfungsi } & \text { beran } \\
\end{array}$ & 3 \\
\hline 28 & $\begin{array}{l}\text { Menu Cetak } \\
\text { Laporan } \\
\text { Peminjaman }\end{array}$ & $\begin{array}{l}\text { Fungsi cetak } \\
\text { laporan } \\
\text { peminjaman } \\
\text { sudah berfungsi } \\
\text { dengan benar }\end{array}$ & 3 \\
\hline 29 & $\begin{array}{l}\text { Menu Cetak } \\
\text { Laporan } \\
\text { Pengebalian }\end{array}$ & $\begin{array}{l}\text { Fungsi cetak } \\
\text { laporan } \\
\text { pengembalian } \\
\text { sudah berfungsi } \\
\text { dengan benar }\end{array}$ & 3 \\
\hline 30 & $\begin{array}{l}\text { Menu Cetak } \\
\text { Laporan } \\
\text { Denda }\end{array}$ & $\begin{array}{lr}\text { Fungsi } & \text { cetak } \\
\text { laporan } & \text { denda } \\
\text { sudah berfungsi } & \text { dengan benar }\end{array}$ & 3 \\
\hline
\end{tabular}

\section{2) Pengujian Usability}

Hasil pengujian usability terhadap 30 responden yang terdiri dari siswa, guru dan pustakawan (operator) dengan jumlah pertanyaan 19 buah. Hasil pengujian sebagai berikut:

Tabel 2. Hasil Pengujian Usability

\begin{tabular}{c|c|c|c|c|c}
\hline \multirow{2}{*}{$\begin{array}{c}\text { No. } \\
\begin{array}{c}\text { Pertanyaan } \\
\text { (Jumlah } \\
\text { item) }\end{array}\end{array}$} & SS & S & RG & TS & STS \\
\cline { 2 - 6 } & 23 & 7 & 0 & 0 & 0 \\
\hline 1 & 26 & 3 & 1 & 0 & 0 \\
\hline 2 & 21 & 7 & 2 & 0 & 0 \\
\hline 3 & 27 & 3 & 0 & 0 & 0 \\
\hline 4 & 26 & 4 & 0 & 0 & 0 \\
\hline 5 & 27 & 3 & 0 & 0 & 0 \\
\hline 6 & 21 & 9 & 0 & 0 & 0 \\
\hline 7 & 22 & 5 & 3 & 0 & 0 \\
\hline 8 & 21 & 8 & 1 & 0 & 0 \\
\hline 9 & 27 & 3 & 0 & 0 & 0 \\
\hline 10 & 21 & 8 & 1 & 0 & 0 \\
\hline 11 & 24 & 6 & 0 & 0 & 0 \\
\hline 12 & 28 & 2 & 0 & 0 & 0 \\
\hline 13 & 28 & 2 & 0 & 0 & 0 \\
\hline 14 & 25 & 5 & 0 & 0 & 0 \\
\hline 15 & 30 & 0 & 0 & 0 & 0 \\
\hline 16 & 26 & 4 & 0 & 0 & 0 \\
\hline 17 & 19 & 11 & 0 & 0 & 0 \\
\hline 18 & 27 & 3 & 0 & 0 & 0 \\
\hline 19 & $\mathbf{4 6 9}$ & $\mathbf{9 3}$ & $\mathbf{8}$ & $\mathbf{0}$ & $\mathbf{0}$ \\
\hline Total & & & &
\end{tabular}

Tabel 3. Nilai Tabel Usability

\begin{tabular}{cccc}
\hline Jenis & Jumlah & Skor & Hasil \\
\hline SS & 469 & 5 & 2345 \\
\hline S & 93 & 4 & 372 \\
\hline RG & 8 & 3 & 24 \\
\hline TS & 0 & 2 & 0 \\
\hline STS & 0 & 1 & 0 \\
\hline \multicolumn{3}{r}{ Skor Total } & \\
\hline
\end{tabular}

Berdasarkan data diatas yang berasal dari jumlah 30 responden, maka secara kontinum rentang data yang dihasilkan sebagai berikut :

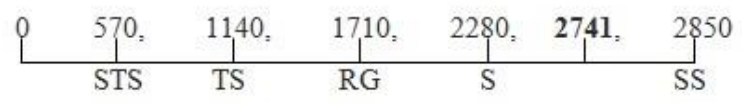

Sehingga hasil perhitungan dari usability yang dilakukan oleh 30 responden, yaitu:

$$
\begin{aligned}
\operatorname{Index}(\%) & =\frac{\text { Jumlah Skor Total }}{\text { Nilai Tertinggi }} \times 100 \\
& =\frac{2741}{2850} \times 100 \\
& =96,18 \%
\end{aligned}
$$

Apabila di interpretasikan nilai 96,18\% dalam sebuah pernyataan maka terletak antara daerah kuat/layak dengan sangat kuat/sangat layak. Sebagaimana dalam tabel interpretasi skor.

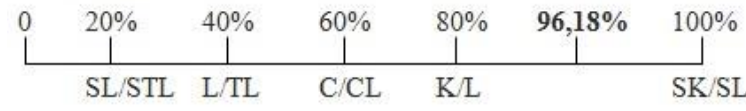

Tabel 4. Tabel Kriteria Interpretasi

\begin{tabular}{cc}
\hline Nilai & Kriteria \\
\hline $0 \%-20 \%$ & $\begin{array}{c}\text { Sangat Lemah/Sangat Tidak } \\
\text { Layak }\end{array}$ \\
\hline $21 \%-40 \%$ & Lemah/Tidak Layak \\
\hline $41 \%-60 \%$ & Cukup/Cukup Layak \\
\hline
\end{tabular}




\begin{tabular}{cc}
\hline $61 \%-80 \%$ & Kuat/Layak \\
\hline $81 \%-100 \%$ & Sangat Kuat/Sangat Layak \\
\hline
\end{tabular}

Berdasarkan hasil pengujian di atas, bahwa pengujian usability pada sistem informasi perpustakaan SMP Negeri 1 Ngaringan dikategorikan "Sangat Kuat/Sangat Layak" dan memenuhi aspek usability.

D. Pembahasan Hasil Penelitian

1) Analisis Pengujian Functionality

Berdasarkan hasil pengujian functionality pada sistem informasi oleh ahli software perpustakaan dapat dihitung menggunakan rumus ISO 9126.

Nilai maksimal yaitu 1, sehingga dapat dikatakan bahwa sistem software sudah memenuhi aspek functionality dengan prosentase keberhasilan 100\%.

\section{2) Analisis Pengujian Usability}

Hasil dari pengujian usability menggunakan metode kuesioner terhadap kualitas perangkat lunak menghasilkan perhitungan dari jumlah jawaban yang diperoleh dikalikan dengan skor di tiap masing-masing pilihan. Adapun tabel perhitungannya sebagai berikut:

Tabel 5. Tabel Analisis Pengujian

\begin{tabular}{cccc}
\multicolumn{4}{c}{ Usability } \\
Jenis & Jumlah & Skor & Hasil \\
\hline SS & 469 & 5 & 2345 \\
\hline S & 93 & 4 & 372 \\
\hline RG & 8 & 3 & 24 \\
\hline TS & 0 & 2 & 0 \\
\hline
\end{tabular}

\begin{tabular}{cccc}
\hline STS & 0 & 1 & 0 \\
\hline & Skor Total & & $\mathbf{2 7 4 1}$ \\
\hline
\end{tabular}

Hasil dari keseluruhan data yaitu 2741, dan berdasarkan prosentase maka sistem informasi perpustakaan ini memperoleh nilai $96,18 \%$.

Berdasarkan data di atas menunjukkan bahwa secara umum sistem informasi perpustakaan SMP Negeri 1 Ngaringan dikatakan sangat kuat/sangat layak secara sistem dan mudah digunakan dalam pengaplikasian untuk mendapatkan informasi perpustakaan bagi pengguna, terutama murid SMP Negeri 1 Ngaringan.

\section{PENUTUP}

Kesimpulan yang diperoleh berdasarkan hasil pembahasan dan penelitian yang dilakukan, dapat disimpulkan bahwa: 1) Perancangan sistem informasi perpustakaan berbasis web yang dikembangkan di SMP Negeri 1 Ngaringan dapat memberikan informasi yang baik bagi sekolah terutama bagi siswa dan pustakawan. 2) Sistem informasi ini juga dapat mengolah kebutuhan administrasi perpustakaan sehingga memberikan kemudahan pelayanan bagi siswa dan terutama bagi pustakawan dalam pengambilan keputusan. 3) Sistem informasi perpustakaan berbasis web di SMP Negeri 1 Ngaringan dalam pengembangannya telah diuji pada aspek functionality dan usability. Hasil dari aspek functionality dengan standar ISO 9126 menyatakan bahwa nilai yang dihasilkan dari sistem ini sebesar $\mathrm{x}=$ 1, yang berarti bahwa sistem ini sudah memenuhi aspek fungsionalitasnya dengan baik sehingga meminimalisir kesalahan dalam pengolahan data. Dan pada aspek usability sistem ini mendapatkan nilai sebesar 96,18\% dan dinyatakan sangat kuat/sangat layak. 


\section{DAFTAR PUSTAKA}

A. S., Rosa dan Shalahuddin, M. 2013. Rekayasa Perangkat Lunak Terstruktur

Dan Berorientasi Objek. Bandung: Informatika.

Arikunto, Suharsimi. 2009. Manajemen Penelitian. Jakarta: Rineka Cipta.

Al Fatta, Hanif. 2007. Analisis dan Perancangan Sistem Informasi untuk Keunggulan Bersaing Perusahaan dan Organisasi Modern. Yogyakarta: ANDI.

Bafadal, Ibrahim. 2008. Pengelolaan Perpustakaan Sekolah. Jakarta: Bumi Aksara

Cahyono, Setiyo. 2006. Panduan Praktis Pemrograman Database Menggunakan MySQL dan Java. Informatika: Bandung.

Darmono. 2007. Perpustakaan Sekolah: Pendekatan Aspek Manajemen dan Tata Kerja. Jakarta: Gramedia Widiasmara Indonesia.

Ervianto, Agus. Rancang Bangun Sistem Informasi Perpustakaan Berbasis Web dengan PHP dan Mysql di Perpustakaan SMA YPPI 1 Surabaya: UNAIR.

Indrajani. 2011. Pengantar dan Sistem Basis Data. Jakarta: PT Elex Media Komputindo.

Ishak. 2008. Pengelolaan Perpustakaan Berbasis Teknologi Informasi. Pustaha: Jurnal Studi Perpustakaan dan Informasi.

Jogiyanto, Hartono. 2004. Pengenalan Komputer. Yogyakarta: Andi Offset.

Jogiyanto, H.M., 2005, Analisa dan Desain Sistem Informasi: Pendekatan Terstruktur Teori dan Praktik Aplikasi Bisnis, Yogyakarta: Andi.

Kadir, Abdul. 2002. Pengenalan Sistem Informasi. Yogyakarta: Penerbit Andi.
Kadir,Abdul. 2003, Konsep dan Tuntunan Praktis Basis Data. Yogyakarta: Andi.

Kristanto, A. 2008. Pengenalan Sistem Informasi. Klaten: Gaya Media.

Mulyanto, Agus. 2009. Sistem Informasi Konsep dan Aplikasi. Yogyakarta: Pustaka Pelajar.

Nielsen, J. 1993. Usability Engineering. Morgan Kaufmann Publishers Inc. San Fransisco.

Permendiknas Nomor 26 Tahun 2008. (2008). Tentang Standar Tenaga Laboratorium Sekolah/Madrasah. Jakarta.

Ramadhani, R. A. 2015. Pengembangan dan Analisis Kualitas Sistem Informasi Perpustakaan Sekolah Berbasis Web di SMK YAPPI Wonosari: UNY.

Riduwan. 2003. Skala Pengukuran Variabel-variabel Penelitian. Bandung: Alfabeta

Siregar, Beiling. 2007. Gedung dan Perlengkapan Perpustakaan, Medan.

Sujadi, 2003. Metodologi Penelitian Pendidikan. Jakarta: Rineka Cipta.

Sugiyono, 2012. Metode Penelitian Kuantitatif Kualitatif dan $R \& D$, Bandung: Alfabeta.

Sugiyono. 2012. Metode Penelitian Pendidikan. Bandung: Alfabeta.

Sukmadinata, Nana Syaodih. 2005. Metode Penelitian Pendidikan, Bandung: Remaja Rosdakarya.

Suryabrata, Sumadi. 1991. Metodologi Penelitian, Jakarta: Rajawali Pers.

Undang-Undang Nomor 43 Tahun 2007. Tentang Perpustakaan.

Wahyono, Teguh. 2004. Sistem Informasi, KonsepDasar, Analisa Desain dan Implementasi. Yogyakarta: Graha Ilmu

Widjajanto, Nugroho, 2008. Sistem Informasi Akuntansi. Jakarta: PT Gelora Aksara Pratama. 